\title{
Schistosomal Cervical Myelopathy
}

\section{Mielopatia esquistossomótica cervical}

\author{
Ronald Farias ${ }^{1}$ Kléver Forte de Oliveira ${ }^{1}$ George de Albuquerque Cavalcanti Mendes ${ }^{1}$ \\ Ussânio Mororó Meira ${ }^{1}$
}

${ }^{1}$ Center of Medical Science, Universidade Federal da Paraíba, João Pessoa, PB, Brazil

Address for correspondence Ronald Farias, MSc, Centro de Ciências Médicas, Universidade Federal da Paraíba, João Pessoa, PB, Brazil

Arq Bras Neurocir 2018;37:151-153.

(e-mail: ronaldfarias@uol.com.br).

\section{Abstract \\ Keywords \\ - schistosoma mansoni \\ - schistosomiasis \\ - neuroschistosomiasis \\ - cervical cord}

\section{Resumo}

\section{Palavras-Chave}

- schistosoma mansoni

- esquistossomose

- neuroesquistossomose

- medula cervical
Schistosomiasis is an infectious disease caused by trematode platyhelminths of the genus Schistosoma. The involvement of the cervical spinal cord is rare, with few cases reported in the literature. The management of such patients is particularly challenging, since clinical and radiological findings may be confounded with other inflammatory diseases and/ or spinal cord tumors. We describe a 20-year old male with a history of swimming outdoors. He first presented pain in the back of the neck extending to shoulders and upper limbs paresis associated with four limbs hyperreflexia. The magnetic resonance imaging (MRI) showed a hypointense T1-weighted lesion in the cervical spinal cord, which was hyperintense on $\mathrm{T} 2$ images. The serologic testing was negative for schistosomiasis. A cervical cord biopsy at the C5-C6 level showed Schistosoma eggs in the histopathological examination. The treatment was performed using a single dose of praziquantel $50 \mathrm{mg} / \mathrm{kg}$, with prednisone $40 \mathrm{mg} /$ day for 3 weeks. On the follow-up, 1 year later, the patient presented mild reduction of the vibratory sensitivity in the distal third of both legs. Our illustrative case strengthens that, in endemic regions, Schistosoma mansoni infestation should be included in the differential diagnosis of intramedullary expansive lesions.

A esquistossomose é uma doença infecciosa causada por platelmintos trematódeos do gênero Schistosoma. O acometimento da medula espinhal cervical é raro, com poucos casos apresentados na literatura. O manejo desses pacientes é particularmente difícil, uma vez que os achados clínicos e radiológicos podem ser confundidos com outras doenças inflamatórias e/ou tumores da medula espinhal. Descrevemos um homem de 20 anos de idade com história de natação ao ar livre. Primeiramente, ele apresentou cervicalgia que se estendeu até os ombros e paresia dos membros superiores, associada à hiperreflexia de quatro membros. A ressonância magnética (RM) mostrou lesão hipointensa em T1 na medula espinhal cervical, a qual foi hiperintensa nas imagens em T2. O teste sorológico foi negativo para esquistossomose. Uma biópsia da medula cervical ao nível C5-C6 evidenciou ovos de Schistosoma no exame histopatológico. O tratamento foi realizado com dose única de praziquantel $50 \mathrm{mg} /$ $\mathrm{kg}$, com prednisona $40 \mathrm{mg} / \mathrm{dia}$ por 3 semanas. No seguimento de 1 ano, o paciente apresentou discreta redução da sensibilidade vibratória no terço distal de ambas as pernas. Nosso caso ilustrativo reforça que, em regiões endêmicas, a infestação pelo Schistosoma mansoni deve ser incluída no diagnóstico diferencial de lesões expansivas intramedulares. received

April 10, 2018

accepted

May 8, 2018
DOI https://doi.org/

10.1055/s-0038-1661356. ISSN 0103-5355.
Copyright $\odot 2018$ by Thieme Revinter Publicações Ltda, Rio de Janeiro, Brazil

License terms

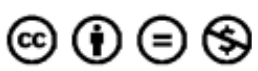




\section{Introduction}

Schistosomiasis is an infectious disease caused by trematode platyhelminths of the genus Schistosoma. Among the species of this genus, the most important for humans are Schistosoma mansoni, Schistosoma haematobium e Schistosoma japonicum. ${ }^{1}$ It is estimated that at least 200 million people are affected by it worldwide, and 200 thousand deaths due to this condition are registered annually, being endemic in Africa, South America and most of Asia. ${ }^{1-3} S$ chistosoma mansoni is the only species existing in Brazil. Around 26 million Brazilians are at risk of contracting it. ${ }^{4}$

The typical manifestations of schistosomiasis include the urogenital, gastrointestinal and hepatolienal systems. The central nervous system involvement by $S$. mansoni is an atypical presentation, occurring by anomalous migration of the schistosome or unusual egg deposition from the portal venous system, through the venous plexus of Batson. ${ }^{3,4}$ This explains the higher prevalence of conus medullaris and thoracolumbar medulla envelopment. The involvement of the cervical spinal cord is rare, with few cases being reported in literature. The management of such patients is particularly challenging, since clinical and radiological findings may be confounded with other inflammatory diseases and/ or spinal cord tumors. ${ }^{3}$

\section{Case Report}

A male patient, 20 years old, white, with previous history of swimming outdoors, presented pain in the back of the neck extending to the shoulders. The neurological examination showed upper limbs paresis $4 / 5$ associated with 4 limbs hyperreflexia. Sensory changes were not found. The magnetic resonance imaging (MRI) showed a hypointense T1-weighted lesion in cervical spinal cord, which was hyperintense on T2 images (-Fig. 1). The biochemical and cytological evaluation of the cerebrospinal fluid (CSF) showed no alterations. Indirect immunofluorescence of CSF for schistosomiasis was negative.

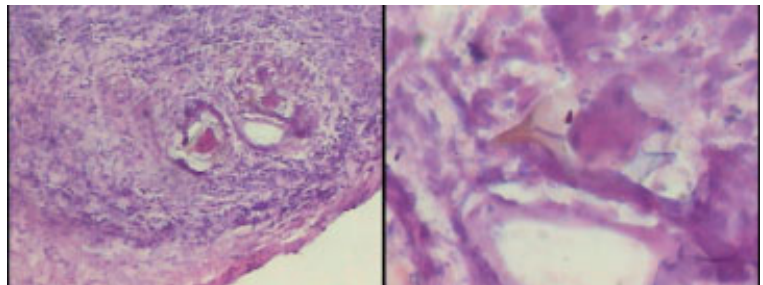

Fig. 2 Histopathological examination of the cervical spinal cord evidencing fibroconjunctive stroma containing remains of Schistosoma mansoni eggs (birefringent material) in the middle of a granulomatous-like inflammatory infiltrate, compatible with the diagnosis of schistosomiasis.

The laboratory tests revealed mild leukocytosis $\left(11,900 / \mathrm{mm}^{3}\right)$ associated with moderate eosinophilia $\left(1,035 / \mathrm{mm}^{3}\right)$. Feces samples (Kato-Katz method) showed no Schistosoma eggs.

A cervical cord biopsy at the $\mathrm{C} 5$ - $\mathrm{C} 6$ level showed a chronic granulomatous inflammatory process with multinucleated giant cells and birefringent material, suggestive of $S$. mansoni eggs (-Fig. 2).

The treatment was performed using a single dose of praziquantel $50 \mathrm{mg} / \mathrm{kg}$, with prednisone $40 \mathrm{mg} /$ day for 3 weeks, performing a gradual withdrawal.

At the one-year postoperative follow-up, the patient presented mild reduction of the vibratory sensitivity in the distal third of both legs. However, he preserved reflexes in the four limbs, with normalization of muscular strength in the upper limbs.

\section{Discussion}

Vascular obstruction occurs both through venous migration of the eggs or direct deposition of these by the parasite in the perimedullary plexus, with formation of granulomas and intense local inflammatory reaction, followed by necrotizing myelitis. There are two clinical forms of schistosomal involvement of the spinal cord: granuloma formation and transverse

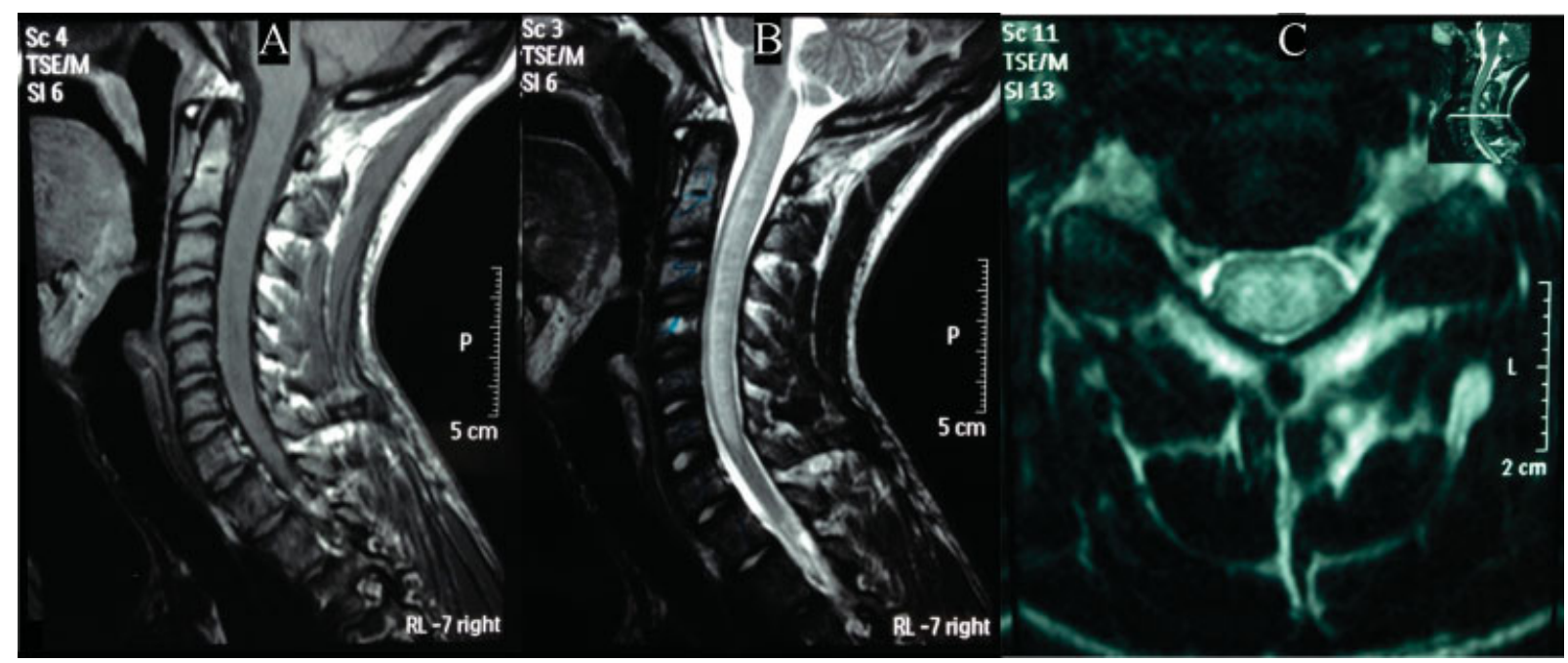

Fig. 1 Preoperative magnetic resonance imaging (MRI). (A) T1-weighted sagittal view, showing hypointense signal in the C4-C6 spinal segments; (B) in the T2-weighted sagittal view, hyperintense signal extending through almost the entire cervical spinal cord. (C) T2 axial view shows hyperintense signal in the cervical spine at the C4-C5 transition level. 
Table 1 Cases of schistosomal myelopathy reported in the literature

\begin{tabular}{|c|c|c|c|}
\hline Case & Clinical Manifestations & Treatment & Outcome \\
\hline $\begin{array}{l}\text { Junker et } a l^{3} \\
(2001)\end{array}$ & $\begin{array}{l}\text { Pain in the four limbs; tetraparesis } \\
\text { associated with the occurrence of } \\
\text { clonus in the legs and hypoesthe- } \\
\text { sia under the T4 level on the left, } \\
\text { and the T8 level on the right }\end{array}$ & $\begin{array}{l}\text { Decompressive laminectomy, } \\
\text { followed by praziquantel, high } \\
\text { doses of corticoid and } \\
\text { physiotherapy }\end{array}$ & $\begin{array}{l}\text { Distal spastic tetraparesis in the } \\
\text { legs and hypoesthesia from the C } 6 \\
\text { level down }\end{array}$ \\
\hline $\begin{array}{l}\text { Silva et al } \\
(2002)\end{array}$ & $\begin{array}{l}\text { Neck pain, tetraparesis, paresthesia } \\
\text { in the four limbs and hypoesthesia at } \\
\text { the } C 5 \text { level }\end{array}$ & $\begin{array}{l}\text { Oxamniquine }(15 \mathrm{mg} / \mathrm{kg} \text { in a single } \\
\text { dose) and prednisone } 60 \mathrm{mg} / \text { day } \\
\text { for } 2 \text { months }\end{array}$ & $\begin{array}{l}\text { Muscle strength improvement and } \\
\text { hypoesthesia resolution; } \\
\text { persistence of left hemi-body } \\
\text { paresthesia }\end{array}$ \\
\hline $\begin{array}{l}\text { Laureys et al } \\
(2007)\end{array}$ & $\begin{array}{l}\text { Pain, tactile hypoesthesia, } \\
\text { hypoalgesia, hypopalesthesia and } \\
\text { decreased distal proprioception in } \\
\text { the legs, associated with flexion } \\
\text { and extension paresis (strength } \\
\text { grade 4); mild gait instability }\end{array}$ & $\begin{array}{l}\text { Praziquantel }(60 \mathrm{mg} / \mathrm{kg} / \text { day for } \\
3 \text { days }) \text { and methylprednisolone } \\
(64 \mathrm{mg} / \text { day })\end{array}$ & $\begin{array}{l}\text { Resolution of pain and sensory } \\
\text { symptoms, as well as marked } \\
\text { motor improvement }\end{array}$ \\
\hline Our case & $\begin{array}{l}\text { Paresis of the upper limbs } \\
\text { (strength grade } 4 \text { ) associated with } \\
\text { hyperreflexia in the } 4 \text { limbs }\end{array}$ & $\begin{array}{l}\text { Single dose of Praziquantel } \\
(50 \mathrm{mg} / \mathrm{kg}) \text { associated with pre- } \\
\text { dnisone (40 mg/day for } 3 \text { weeks, } \\
\text { performing a gradual withdrawal) }\end{array}$ & $\begin{array}{l}\text { Hypopalesthesia in the distal third } \\
\text { of both legs; preserved reflexes in } \\
\text { the } 4 \text { limbs, with normalization of } \\
\text { muscular strength (grade } 5 \text { ) in the } \\
\text { upper limbs }\end{array}$ \\
\hline
\end{tabular}

myelitis. $^{3}$ The schistosomal myelopathy (SM) prevalence is unknown. However, strong evidences indicate it is an underdiagnosed condition. ${ }^{1,4}$ The typical patient of this disease is young, male, presenting low back or lower limbs pain, usually of radicular pattern, followed by weakness and progressive sensorial loss in the lower limbs, associated with autonomic dysfunction, mainly of the bladder. ${ }^{1}$

The diagnosis is primarily based on clinical examination. The MRI usually presents hyperintense T2-weighted lesions, which are isointense on T1 images. ${ }^{2}$ The laboratory tests of CSF reveal nonspecific findings. ${ }^{1,4}$ Our patient presented normal protein and glucose levels; pleocytosis was not evidenced.

The SM treatment is based on the association of an anthelmintic (praziquantel or oxamniquine) and a corticosteroid. In cases of granuloma formation, a surgical approach with decompression is indicated. ${ }^{1,2}$

Reports of cervical spinal cord schistosomiasis have been previously published. Junker et $\mathrm{al}^{3}$ and Laureys et $\mathrm{al}^{2}$ reported cases of neuroschistosomiasis presenting as transverse myelitis in men in their fourth decade. A decompressive laminectomy was performed in the first case due to acute incomplete tetraparesis and evidence of spinal stenosis at MRI. Silva et $\mathrm{al}^{5}$ described a case of granuloma formation case in a 34 years old male. In the three cases, the patients presented sensory and motor impairment, in addition to pain. The proposed pharmacological treatment was similar to our case (anthelmintic and corticosteroid), as well as the clinical outcome (sensory and motor improvement and pain resolution) (-Table $\mathbf{1}$ ).

\section{Conclusion}

Cervical myelopathy is an extremely rare presentation of Schistosomiasis. Our illustrative case strengthens that, in endemic regions, S. mansoni infestation should be included in the differential diagnosis of intramedullary expansive lesions. The diagnosis is based on clinical and radiological findings, and pharmacologic therapy is the primary treatment approach. Surgical decompression and biopsy are reserved to patients in whom no clinical improvement is observed after institution of antischistosomal medications and/or in case of neurological deterioration. Only in such cases, surgery should be indicated. The SM prognosis is excellent when the diagnosis is early, and the treatment is appropriate. ${ }^{1,3}$

\section{Conflicts of Interest}

The authors declare that there are no conflicts of interest.

\section{References}

1 Ferrari TCA, Moreira PRR, Cunha AS. Spinal cord schistosomiasis: a prospective study of 63 cases emphasizing clinical and therapeutic aspects. J Clin Neurosci 2004;11(03):246-253. Doi: 10.1016/j.jocn.2003.05.006

2 Laureys G, Chaskis C, Bourgain C, Stadnik T, Dielman C, Ebinger G. A case of 'tropical' myelopathy. Acta Neurol Belg 2007;107(04): 131-133

3 Junker J, Eckardt L, Husstedt I. Cervical intramedullar schistosomiasis as a rare cause of acute tetraparesis. Clin Neurol Neurosurg 2001;103(01):39-42. Doi: 10.1016/S0303-8467(00)00124-4

4 Henriques-Souza AMDM, Valença MM. Schistosomal myelopathy in childhood: findings of magnetic resonance imaging in 26 patients. Pediatr Neurol 2011;45(06):373-376. Doi: 10.1016/j. pediatrneurol.2011.09.006

5 Silva LCS, Kill CM, Lambertucci JR. Cervical spinal cord schistosomiasis. Rev Soc Bras Med Trop 2002;35(05):543-544. Doi: 10.1590/S0037-86822002000500023 